\title{
Intervensi biskuit tempe kurma bagi peningkatan status gizi balita penderita tuberkulosis
}

\author{
The intervention of tempeh dates biscuit on the improved nutritional status of tuberculosis preschoolers \\ patients
}

Fatmah $^{1}$

\begin{abstract}
Background: Weight gain as an indicator of nutritional status during tuberculosis drugs management has a significant relationship with the rapid conversion of sputum smear, low incidence of relapse and duration of anti tuberculosis drugs in patients with tuberculosis. Low intake of food in patient suffering from an infectious disease is caused by the emergence of anorexia, nausea, vomiting, and increased body temperature. Inadequate nutrient intake affect the immune system, lower resistance to infection and slow healing resulting progessive tuberculosis (TB).

Objective: To assess the effect of tempeh dates biscuit consumption on the change of nutritional status of tuberculosis preschoolers patients.

Method: A quasi experimental design towards 52 underfive children with TB status and who were underweight was done in all sub districts at Depok City. There were three groups participated in the study i.e tempeh dates biscuits as intervention group, and two groups of control (tempeh and placebo biscuits). The nutritional status of subjects was assessed each biweekly by giving daily 50 grams of biscuits within four weeks. Data analysis was using paired t-test and Anova.

Results: There were greatest weight gain in subject who received tempeh dates biscuit by $0.5 \mathrm{~kg}$ and largest height improvement in the tempeh biscuits group by $1.8 \mathrm{~cm}$. Weight, height, and z-score weight/age had significant differences in the three groups at the end of the study. There were significant differences on carbohydrate intake in the intervention group at pre and postintervention. Tempeh biscuits group had different levels of mothers' knowledge on nutrition and TB at the end of the study. Conclusion: Tempeh dates biscuit can be recommended as an alternative supplementation feeding program for TB and non TB underfive children with underweight status.
\end{abstract}

KEY WORDS: tempeh dates biscuit, underfive tuberculosis children, underweight

\begin{abstract}
ABSTRAK
Latar belakang: Peningkatan berat badan sebagai salah satu indikator status gizi selama pemberian obat anti tuberkulosis (OAT) memiliki hubungan bermakna dengan cepatnya konversi sputum bakteri tahan asam (BTA), rendahnya kejadian relaps, dan lamanya pemberian OAT pada penderita tuberkulosis (TB). Rendahnya asupan makanan pada seseorang yang sedang menderita infeksi disebabkan oleh munculnya anoreksia, mual, muntah, dan suhu badan yang meningkat. Asupan gizi yang tidak memadai berdampak terhadap sistem imunitas dan penurunan daya tahan tubuh. Selain itu, infeksi menjadi progesif yang mengakibatkan lambatnya penyembuhan TB.

Tujuan: Mengetahui pengaruh konsumsi biskuit padat gizi terbuat dari tepung tempe dan selai kurma sebagai pemberian makanan tambahan (PMT) pemulihan pada perubahan status gizi kurang balita TB.

Metode: Desain quasi experimental ditujukan pada 52 balita penderita TB berstatus gizi kurang di seluruh kecamatan Kota Depok yang terbagi pada 3 kelompok yaitu kelompok perlakuan biskuit tempe kurma dan dua kelompok kontrol (biskuit tempe dan biskuit plasebo). Pengukuran status gizi dinilai setiap dua minggu sekali setelah subjek diberikan 50 gram biskuit setiap hari selama 4 minggu. Data dianalisis menggunakan paired t-test dan Anova.

Hasil: Kenaikan berat badan terbesar $(0,5 \mathrm{~kg})$ terdapat pada balita penerima biskuit tempe kurma dan peningkatan tinggi badan terbesar pada balita kelompok biskuit tempe $(1,8 \mathrm{~cm})$. Berat badan, tinggi badan, dan z-skor BB/U berbeda bermakna pada ketiga kelompok di akhir studi. Asupan karbohidrat antar kelompok sebelum dan setelah perlakuan menunjukkan perbedaan yang bermakna. Tingkat pengetahuan ibu balita tentang gizi dan TB pada kelompok biskuit tempe menunjukkan perbedaan bermakna di akhir studi.

Simpulan: Biskuit tempe kurma dapat direkomendasikan sebagai salah satu alternatif makanan PMT pemulihan bagi balita gizi kurang penderita TB maupun non penderita TB.
\end{abstract}

KATA KUNCI: biskuit tempe kurma, balita TB, gizi kurang, PMT pemulihan

\section{PENDAHULUAN}

Penyakit tuberkulosis (TB) adalah penyakit infeksi kronis menular yang masih menjadi masalah kesehatan masyarakat di dunia termasuk di Indonesia. Indonesia
${ }^{1}$ Departemen Gizi Kesehatan Masyarakat, Fakultas Kesehatan Masyarakat Universitas Indonesia, Gedung F Lt. 2 Ruang F202 Kampus UI Depok 16424, Telp. (021) 7863501, Fax. (021) 7863501 e-mail: ffatmah@yahoo.com 
termasuk peringkat ketiga setelah India dan China dalam menyumbang jumlah kasus TB di dunia (1). Prevalensi TB di Indonesia semakin meningkat dan di Amerika Serikat ditemukan $45 \%$ pasien tergolong berat badan kurang dan $26 \%$ mengalami anoreksia setelah didiagnosis menderita TB (2). Status gizi kurang pada pasien TB terjadi akibat proses penyakit itu sendiri dan keterlambatan diagnosis. Status gizi yang buruk akan memperlambat penyembuhan dan meningkatkan frekuensi kekambuhan. Seringkali pasien TB yang telah menjalani pengobatan selama 6 bulan terus menerus belum mengalami peningkatan berat badan (3). Berat badan seseorang berhubungan dengan risiko penyakit, derajat beratnya penyakit, dan respon terapi. Asupan gizi yang baik pada awal pengobatan TB akan meningkatkan berat badan, massa tubuh bebas lemak, dan fungsi fisik. Status gizi yang baik selama masa pengobatan akan menurunkan prevalensi kambuhnya penyakit, mempercepat konversi sputum bakteri tahan asam (BTA) setelah obat anti tuberkulosis (OAT), dan mempersingkat masa pengobatan (4).

Penyakit TB menjadi prioritas utama di Kota Depok karena masih banyaknya kasus TB di masyarakat terutama pada penduduk dengan ekonomi lemah. Hasil pelacakan balita gizi buruk oleh Dinas Kesehatan (Dinkes) Kota Depok pada tahun 2010 dengan menggunakan indikator berat badan per umur (BB/U), ditemukan 38,6\% balita sangat kurus dan $26,5 \%$ balita kurus (5). Tiga perempat balita gizi buruk $(75,2 \%)$ tersebut berasal dari keluarga miskin (GAKIN). Seperempatnya $(25,1 \%)$ menderita penyakit infeksi TB, TB tulang, infeksi saluran pernapasan atas (ISPA), dan diare. Bahkan, ada 1 balita gizi buruk juga menderita HIVIAIDS. Sementara itu, permasalahan yang dihadapi oleh Dinkes Kota Depok dalam menangani TB anak balita adalah belum adanya dana pendamping yang dialokasikan oleh Pemerintah Kota Depok untuk meningkatkan status gizi balita TB, padahal hampir $25 \%$ balita gizi buruk menderita penyakit TB. Oleh karena itu, perbaikan gizi kurang melalui pemberian makanan tambahan (PMT) pemulihan yang tinggi energi dan tinggi protein sangat dibutuhkan oleh balita TB untuk memperbaiki status gizinya.

Tiga studi sebelumnya menunjukkan bahwa pemberian makanan tambahan dapat meningkatkan status gizi penderita TB. Studi pertama menunjukkan bahwa makanan tinggi protein (soy protein) sebagai makanan tambahan selama 1-2 bulan dapat memperbaiki status gizi penderita TB. Studi kedua tentang pengaruh konsumsi biskuit tempe kurma terhadap perubahan status gizi balita gizi kurang di dua kelurahan terpilih di Kota Depok menunjukkan rata-rata kenaikan berat badan paling besar pada kelompok biskuit tempe kurma (1,3 $\mathrm{kg})$ dan tinggi badan pada kelompok biskuit tempe $(2,8 \mathrm{~cm})$ selama 4 minggu masa intervensi. Studi terakhir pada balita TB di wilayah Jakarta Timur menunjukkan kenaikan berat badan dan tinggi badan pada sampel penerima biskuit tempe kurma masing-masing sebesar 0,4 kg dan 3,4 cm (6-8). Studi ketiga ini berbeda dengan dua studi sebelumnya karena kriteria inklusi sampel adalah pasien balita TB kurang gizi.

Pada studi ini, pemilihan bahan dasar biskuit dari tepung tempe dan selai kurma karena kandungan protein yang tinggi pada tempe (62\% dalam 166 gram tempe murni) dan kandungan karbohidrat (glukosa), vitamin A, dan zink yang tinggi pada kurma. Kurma meningkatkan berat badan anak karena dapat meningkatkan nafsu makannya. Zink dapat meningkatkan imunitas tubuh yang dibutuhkan oleh pasien TB guna memperbaiki sistem imun dan mempersingkat masa pemberian OAT (9-11). Selain itu, penelitian efikasi biskuit tempe kurma bagi balita pasien TB dengan gizi kurang belum pernah dilakukan baik di Indonesia maupun di luar negeri. Tujuan studi ini adalah untuk menilai pengaruh konsumsi biskuit tempe kurma terhadap perubahan status gizi secara antropometri pada balita penderita TB dengan status gizi kurang di Kota Depok selama 4 minggu intervensi.

\section{BAHAN DAN METODE}

Desain Randomized Clinical Trial (RCT) digunakan dalam studi ini pada 49 sampel di Kota Depok yang dilaksanakan selama bulan Juli 2012. Ethical Clearance diperoleh dari Komite Etika Penelitian Badan Penelitan dan Pengembangan Kesehatan Kementerian Kesehatan Republik Indonesia. Populasi penelitian adalah seluruh balita penderita TB di wilayah Jakarta Timur. Sampel penelitian adalah balita penderita TB yang memenuhi kriteria inklusi yaitu balita berusia 12-59 bulan dengan TB paru yang merupakan kasus baru (belum pernah mendapatkan OAT) atau kasus lama minimal telah mengikuti pengobatan OAT selama 4 bulan sehingga di akhir intervensi subjek telah menyelesaikan lama pengobatan OAT-nya selama 6 bulan, memiliki status gizi kurang (z-score BB/U < -2 SD) (12), dan adanya informed consent dari orang tua terutama ibu balita sebagai pernyataan kesediaan mengikuti sampai akhir penelitian. Kriteria eksklusinya adalah balita pasien TB yang sedang menjalani diit khusus dan atau sedang menderita penyakit kronik.

Besar sampel ditentukan dengan rumus uji perbedaan mean dua kelompok independen dengan pertambahan berat badan sampel dari penelitian sebelumnya sebesar $0,4 \mathrm{~kg}$ (7); tingkat kemaknaan ( $\mathrm{Z \alpha}$ ) sebesar 1,96; dan kekuatan uji $(Z \beta)$ sebesar 0,84. Sampel minimal pada masing-masing kelompok sebesar 15 orang yang diperbesar $30 \%$ menjadi 20 orang sehingga total sampel sebesar 60 orang yang terbagi dalam 3 kelompok (biskuit tempe kurma, biskuit tempe, dan biskuit plasebo).

Skrining awal status gizi dilakukan melalui pengukuran antropometri berat dan tinggi badan pada 100 balita TB yang diperoleh dari puskesmas kecamatan terpilih dan 


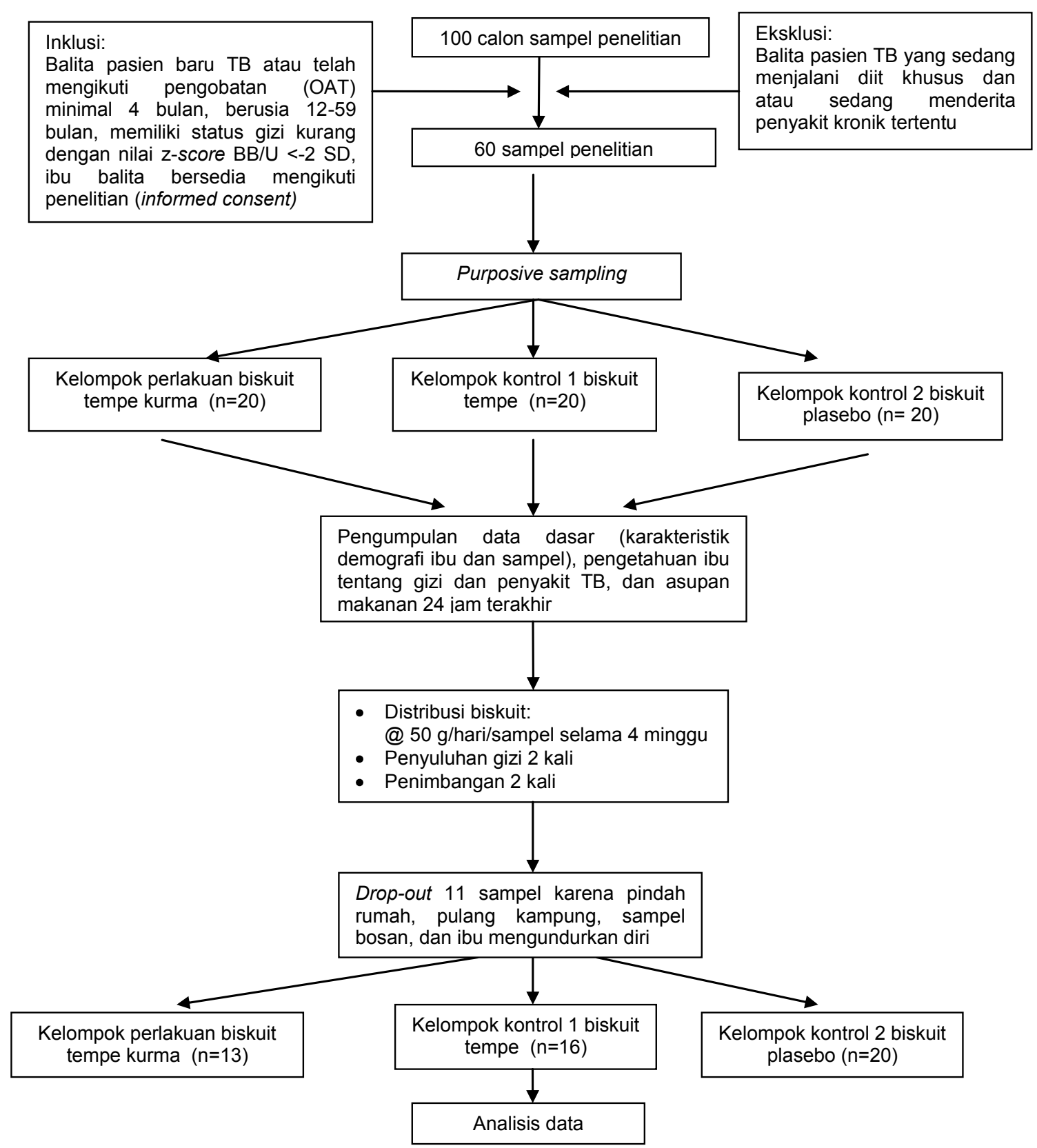

Gambar 1. Alur penelitian

rumah sakit umum daerah (RSUD) Kota Depok. Setiap subjek penelitian menerima 50 gram biskuit setiap harinya selama 4 minggu yang bisa dikonsumsi kapanpun sesuai keinginan subjek. Subjek penelitian dibedakan ke dalam tiga kelompok yaitu kelompok perlakuan (biskuit tempe kurma) dan dua kelompok kontrol (biskuit tempe dan plasebo) (Gambar 1). Lama intervensi empat minggu atau satu bulan berdasarkan studi sebelumnya pada balita kurus yang diberikan PMT lokal selama sebulan. Hasil penelitian tersebut menunjukkan perbedaan yang bermakna antara status gizi (z-score BB/TB) pada balita gizi kurus sebelum dan sesudah pemberian PMT lokal (13). Biskuit tempe kurma dibuat dari tepung terigu, tepung tempe, maizena, selai kurma, telur, mentega, dan gula halus. Perbandingan komposisi tepung tempe dengan selai kurma dalam 100 gram biskuit tempe kurma adalah 1:1. Biskuit tempe berbahan dasar sama dengan biskuit tempe kurma kecuali selai kurma. Demikian juga dengan biskuit plasebo yang berbahan dasar sama dengan kedua jenis biskuit tersebut kecuali tepung tempe dan selai kurma.

Variabel bebas penelitian adalah berat badan balita sebelum penelitian dan variabel terikatnya adalah berat badan setelah penelitian. Hal ini didasari oleh sensitifnya perubahan berat badan pada pasien TB yang menjadi tolok ukur tingkat kesembuhannya. Variabel pengganggu dalam penelitian ini yaitu pengetahuan ibu tentang gizi dan TB serta asupan zat gizi makro dan mikro. Data antropometri berat badan diukur menggunakan timbangan digital SECA oleh tenaga lapangan terlatih. Indikator z-score berat badan menurut umur (BB/U) kurang dari -2 SD digunakan 
untuk menetapkan status gizi kurang (12). Penggunaan indikator BB/U dalam penelitian ini berdasarkan indikator status gizi pasien TB selama pemberian OAT yaitu apabila berat badan cenderung naik maka indikasinya adalah pasien dalam proses penyembuhan.

Penyuluhan gizi TB dilakukan sebanyak 2 kali di tengah-tengah studi menggunakan lembar balik dan slide presentasi oleh peneliti kepada seluruh responden ibu balita yang bertempat di RSUD Kota Depok. Kemudian, pengetahuan ibu balita tentang gizi dan TB dinilai pada awal dan akhir penelitian dari rerata skornya berdasarkan 10 pertanyaan dalam kuesioner. Tingkat pendidikan akhir ibu balita dikategorikan menjadi dua yaitu rendah dan sedang dengan indikator lama menempuh pendidikan minimal 9 tahun (14). Asupan zat gizi makro antara lain adalah energi, karbohidrat, protein, dan lemak sedangkan asupan zat gizi mikro meliputi vitamin $A$, vitamin $C$, vitamin B6, dan zink (Zn).

Pengukuran antropometri dan pengetahuan ibu dilakukan 2 kali yaitu di awal dan akhir perlakuan sedangkan pencatatan konsumsi makanan harian subjek dilakukan melalui kunjungan rumah sebanyak 12 kali (3 kali setiap minggu) selama studi berlangsung. Pengambilan data dilakukan oleh enumerator dengan pendidikan akhir Sarjana Gizi (SGz) Fakultas Kesehatan Masyarakat, Universitas Indonesia. Distribusi biskuit tempe kurma, biskuit tempe, dan plasebo dilakukan melalui kunjungan rumah balita oleh tim peneliti dan kader posyandu sebanyak tiga sekali seminggu sekaligus mengumpulkan form catatan makanan harian (24 hours food recall). Total kunjungan adalah 12 kali selama penelitian berlangsung.

Data antropometri berat badan subjek dianalisis dengan software WHO Anthroplus versi 02 tahun 2009 (15). Data konsumsi makanan untuk menilai kecukupan asupan zat gizi makro dan mikro dianalisis dengan nutrisurvey dan selanjutnya dibandingkan dengan angka kecukupan gizi (AKG) anak usia 12-59 bulan (16). Analisis data univariat dan bivariat dilakukan dengan program SPSS version 13. Uji paired t-test untuk menilai perubahan rerata asupan gizi, berat badan, tinggi badan pre-post intervensi pada tiap kelompok. Uji Anova digunakan untuk menilai rerata seluruh variabel-variabel tersebut berdasarkan kelompok (antar kelompok).

\section{HASIL}

\section{Karakteristik subjek penelitian}

Rerata usia subjek yang tertinggi ditemukan pada kelompok biskuit plasebo dan terendah pada kelompok biskuit tempe kurma. Demikian pula dengan lama menderita penyakit TB sedangkan usia ibu yang tertinggi terdapat pada sampel kelompok biskuit tempe dan terendah pada kelompok biskuit tempe kurma. Tidak ditemukan adanya perbedaan bermakna antara usia balita, lama balita menderita TB, dan usia ibu pada ketiga kelompok baik perlakuan maupun kontrol $(p>0,05)$ (Tabel 1). Sebagian besar subjek pada kedua kelompok kontrol berjenis kelamin laki-laki (34,6\% untuk kelompok biskuit tempe dan $46,2 \%$ untuk kelompok plasebo). Perbandingan subjek perempuan pada kelompok perlakuan dan kontrol adalah sama yaitu 1:1. Tingkat pendidikan akhir sedang ( $\geq 9$ tahun) paling banyak dimiliki oleh ibu pada kelompok kontrol (38,9\% untuk kelompok biskuit tempe dan 36,1\% untuk kelompok plasebo). Namun, jenis kelamin subjek dan tingkat pendidikan akhir ibu tidak berbeda bermakna antara ketiga kelompok $(p>0,05)$.

\section{Pengetahuan ibu tentang gizi dan TB serta asupan zat gizi balita}

Tabel 2 menunjukkan peningkatan rerata asupan zat gizi balita sesudah perlakuan terutama pada kelompok tempe kurma. Meskipun demikian, masih terdapat penurunan asupan zat gizi makro dan mikro terutama pada asupan vitamin B6 yang menurun pada semua kelompok perlakuan. Peningkatan terbesar pengetahuan ibu balita tentang gizi dan penyakit TB terdapat pada kelompok biskuit tempe dan peningkatan terendah pada kelompok biskuit plasebo. Tidak terdapat perbedaan skor perubahan pengetahuan tersebut berdasarkan kelompok ( $p>0,05)$ kecuali pada kelompok biskuit tempe $(p<0,05)$ (Tabel 3). Asupan karbohidrat setelah intervensi berbeda bermakna antar kelompok $(p<0,05)$. Peningkatan asupan karbohidrat paling besar terdapat pada kelompok biskuit tempe kurma dibandingkan dua kelompok kontrol. Sebaliknya, kelompok plasebo mengalami penurunan asupan karbohidrat sebesar 8,8 gram selama studi berjalan. Kelompok perlakuan menunjukkan peningkatan asupan energi dan lemak yang tertinggi dibandingkan kelompok kontrol. Namun, asupan protein menurun pada kelompok biskuit plasebo sebesar 1,8 gram.

Peningkatan asupan vitamin A pada kelompok biskuit tempe paling tinggi dibandingkan dengan dua kelompok lainnya. Selain itu, terdapat kenaikan asupan vitamin C sebesar 1,2 gram pada kelompok perlakuan dan sebaliknya terjadi penurunan asupan vitamin $\mathrm{C}$ pada kedua kelompok kontrol $(p<0,05)$ sedangkan penurunan asupan vitamin B6 terjadi pada ketiga kelompok. Kelompok biskuit plasebo mengkonsumsi makanan sumber $\mathrm{Zn}$ terbesar yang diikuti oleh kelompok biskuit tempe kurma (Tabel 3).

\section{Perubahan status gizi balita}

Berat badan subjek pada kelompok biskuit tempe kurma mengalami peningkatan tertinggi di akhir intervensi sebesar 0,5 kg dibandingkan dua kelompok lainnya. Berat badan subjek antar kelompok tidak berbeda bermakna $(p>0,05)$, tetapi berbeda bermakna masing-masing pada kelompok biskuit tempe kurma dan biskuit tempe $(p<0,05)$. Tinggi badan subjek pada kelompok biskuit 
Tabel 1. Karakteristik subjek penelitian

\begin{tabular}{lcccc}
\hline \multirow{2}{*}{ Variabel } & \multicolumn{3}{c}{ Kelompok perlakuan (Rerata \pm SD) } & \multirow{2}{*}{ p } \\
\cline { 2 - 4 } & Tempe kurma & Tempe & Plasebo & 0,122 \\
Umur balita (bulan) & $27,8 \pm 15,8$ & $34,6 \pm 16,2$ & $40,2 \pm 17,2$ & 0 \\
Lama menderita TB (bulan) & $4,2 \pm 3,0$ & $5,5 \pm 5,8$ & $6,7 \pm 5,9$ & 0,489 \\
Umur ibu (tahun) & $30,2 \pm 6,5$ & $34,1 \pm 7,1$ & $32,7 \pm 5,8$ & 0,285 \\
\hline
\end{tabular}

Tabel 2. Rerata asupan zat gizi balita sebelum dan sesudah perlakuan

\begin{tabular}{|c|c|c|c|c|c|c|}
\hline \multirow{3}{*}{ Variabel } & \multicolumn{6}{|c|}{ Kelompok perlakuan (Rerata $\pm S D)$} \\
\hline & \multicolumn{2}{|c|}{ Tempe kurma } & \multicolumn{2}{|c|}{ Tempe } & \multicolumn{2}{|c|}{ Plasebo } \\
\hline & Sebelum & Sesudah & Sebelum & Sesudah & Sebelum & Sesudah \\
\hline \multicolumn{7}{|l|}{ Asupan zat gizi makro } \\
\hline Energi (kkal) & $781,5 \pm 145,3$ & $1052,3 \pm 225,3$ & $750,3 \pm 245,6$ & $934,8 \pm 275,5$ & $809,7 \pm 300,4$ & $875,9 \pm 185,5$ \\
\hline Karbohidrat (g) & $147,8 \pm 32,8$ & $180,4 \pm 36,4$ & $120,4 \pm 25,5$ & $139,8 \pm 35,5$ & $139,3 \pm 30,4$ & $130,5 \pm 17,5$ \\
\hline Protein $(\mathrm{g})$ & $33,8 \pm 7,8$ & $35,5 \pm 15,7$ & $31,1 \pm 21,6$ & $30,5 \pm 10,4$ & $30,3 \pm 11,4$ & $28,5 \pm 20,5$ \\
\hline Lemak $(\mathrm{g})$ & $30,1 \pm 10,2$ & $45,3 \pm 15,0$ & $31,6 \pm 10,8$ & $43,5 \pm 9,3$ & $28,0 \pm 15,1$ & $40,3 \pm 7,5$ \\
\hline \multicolumn{7}{|l|}{ Asupan zat gizi mikro } \\
\hline Vitamin A (mcg RE) & $575,0 \pm 276,0$ & $737,8 \pm 350,3$ & $580,5 \pm 650,3$ & $783,1 \pm 275,5$ & $450,5 \pm 516,5$ & $609,2 \pm 450,3$ \\
\hline Vitamin C (mg) & $30,5 \pm 20,5$ & $31,7 \pm 35,4$ & $54,7 \pm 33,5$ & $35,2 \pm 30,5$ & $30,4 \pm 28,9$ & $29,7 \pm 26,5$ \\
\hline Vitamin B6 (mg) & $0,3 \pm 0,1$ & $0,2 \pm 0,2$ & $0,3 \pm 0,2$ & $0,2 \pm 0,2$ & $0,4 \pm 0,3$ & $0,2 \pm 0,3$ \\
\hline $\mathrm{Zn}(\mathrm{mg})$ & $3,4 \pm 1,3$ & $4,2 \pm 3,4$ & $5,0 \pm 8,7$ & $6,6 \pm 9,9$ & $4,5 \pm 3,3$ & $6,7 \pm 2,5$ \\
\hline
\end{tabular}

Tabel 3. Perubahan rerata pengetahuan ibu tentang gizi dan TB serta asupan zat gizi balita

\begin{tabular}{lcccc}
\hline \multicolumn{1}{c}{ Variabel } & \multicolumn{2}{c}{ Kelompok perlakuan (Rerata \pm SD) } & \multirow{2}{*}{ p } \\
\cline { 2 - 4 } & Tempe kurma & Tempe & Plasebo & \\
\hline Skor perubahan pengetahuan ibu & $0,7 \pm 1,5$ & $1,8 \pm 2,1$ & $0,5 \pm 1,7$ & 0,098 \\
P & 0,121 & $0,004^{*}$ & 0,196 & \\
Perubahan asupan zat gizi makro & & & & \\
Energi (kkal) & $270,5 \pm 225,4$ & $184,6 \pm 240,3$ & $66,2 \pm 301,5$ & 0,117 \\
Karbohidrat (g) & $32,6 \pm 32,7$ & $19,4 \pm 34,6$ & $-8,8 \pm 41,3$ & $0,013^{*}$ \\
Protein (g) & $1,7 \pm 7,8$ & $0,8 \pm 11,6$ & $-1,8 \pm 11,4$ & 0,651 \\
Lemak (g) & $15,2 \pm 12,2$ & $11,9 \pm 10,8$ & $12,3 \pm 15,1$ & 0,767 \\
Perubahan asupan zat gizi mikro & & & & \\
Vitamin A (mcg RE) & $162,8 \pm 370,3$ & $202,6 \pm 1.684,4$ & $158,7 \pm 1896,5$ & 0,792 \\
Vitamin C (mg) & $1,2 \pm 15,4$ & $-19,5 \pm 16,7$ & $-0,7 \pm 15,3$ & $0,001^{*}$ \\
Vitamin B6 (mg) & $-0,1 \pm 0,2$ & $-0,1 \pm 0,2$ & $-0,2 \pm 0,3$ & 0,467 \\
Zn (mg) & $1,8 \pm 4,1$ & $1,6 \pm 9,9$ & $2,2 \pm 6,6$ & 0,971 \\
\hline Keterangan: * ${ }^{*}$ bermakna $(\mathrm{p}<0,05)$ & & & &
\end{tabular}

tempe mengalami peningkatan terbesar yaitu $1,8 \mathrm{~cm}$ yang selanjutnya diikuti oleh subjek pada kelompok biskuit tempe kurma sebesar $1,7 \mathrm{~cm}$. Ketiga kelompok memiliki perbedaan tinggi badan yang bermakna $(p<0,05)$, demikian pula masing-masing subjek pada setiap kelompok.

Subjek pada kelompok biskuit tempe kurma yang semula berstatus gizi kurang di awal studi berubah menjadi status gizi normal di akhir studi. Demikian juga pada kelompok biskuit tempe meskipun masih mendekati batas kriteria gizi kurang ( $z$-score $B B / U=-1,9)$. Berbeda dengan subjek pada kelompok plasebo yang masih menderita gizi kurang. Rerata z-score BB/U memiliki perbedaan bermakna antar kelompok dan di dalam kelompok itu sendiri yaitu kelompok biskuit tempe kurma dan biskuit tempe kecuali kelompok biskuit plasebo (Tabel 4).

\section{Gambaran biskuit}

Kandungan zat gizi makro dan empat zat gizi mikro per 100 gram dari ketiga jenis biskuit disajikan pada Tabel 5. Biskuit tempe 100 gram mengandung energi (516 kkal), lemak (27,5 gram), dan Zn (1,46 mg) yang paling besar dibandingkan biskuit tempe kurma dan plasebo. Namun, biskuit tempe kurma mengandung protein $(8,44$ gram) dan vitamin $C(0,82 \mathrm{mg})$ terbesar dibandingkan biskuit tempe dan plasebo. Sementara itu, biskuit plasebo hanya mengandung tinggi karbohidrat $(70,4$ gram) dan kandungan $\mathrm{Zn}$ yang sama dengan biskuit tempe kurma. Gambaran fisik biskuit pada masing-masing perlakuan dapat dilihat pada Gambar 1, 2, dan 3. 
Tabel 4. Perubahan rerata berat badan, tinggi badan, dan z-score BB/U subjek sebelum dan sesudah perlakuan

\begin{tabular}{|c|c|c|c|c|c|c|c|c|c|c|}
\hline \multirow[t]{2}{*}{ Variabel } & \multicolumn{3}{|c|}{$\begin{array}{c}\text { Tempe kurma } \\
(n=14)\end{array}$} & \multicolumn{3}{|c|}{$\begin{array}{c}\text { Biskuit tempe } \\
(n=18)\end{array}$} & \multicolumn{3}{|c|}{$\begin{array}{c}\text { Plasebo } \\
(n=20)\end{array}$} & \multirow[t]{2}{*}{$\mathbf{p}^{\mathbf{a}}$} \\
\hline & Rerata & & SD & Rerata & & SD & Rerata & & SD & \\
\hline \multicolumn{11}{|l|}{ Berat badan } \\
\hline Sebelum & 9,7 & \pm & 2,8 & 10,3 & \pm & 2,7 & 11,4 & \pm & 2,7 & 0,193 \\
\hline Sesudah & 10,2 & \pm & 2,8 & 10,7 & \pm & 2,8 & 11,5 & \pm & 2,8 & 0,394 \\
\hline Selisih & 0,5 & \pm & 0,0 & 0,4 & \pm & 0,5 & 0,10 & \pm & 0,6 & 0,102 \\
\hline$p^{b}$ & \multicolumn{3}{|c|}{$0,004^{*}$} & \multicolumn{3}{|c|}{$0,002^{*}$} & \multicolumn{3}{|c|}{0,337} & \\
\hline \multicolumn{11}{|l|}{ Tinggi badan } \\
\hline Sebelum & 80,9 & \pm & 11,9 & 83,9 & \pm & 11,5 & 88,99 & \pm & 11,8 & 0,142 \\
\hline Sesudah & 82,6 & \pm & 11,5 & 85,7 & \pm & 11,9 & 89,65 & \pm & 11,6 & 0,226 \\
\hline Selisih & 1,7 & \pm & 1,0 & 1,8 & \pm & 1,7 & 0,66 & \pm & 0,5 & $0,006^{*}$ \\
\hline$p^{b}$ & \multicolumn{3}{|c|}{$0,001^{*}$} & \multicolumn{3}{|c|}{$0,001^{*}$} & \multicolumn{3}{|c|}{$0,001^{*}$} & \\
\hline \multicolumn{11}{|l|}{ z-score BB/U } \\
\hline Sebelum & $-2,10$ & \pm & 1,3 & $-2,10$ & \pm & 1,1 & $-2,16$ & \pm & 1,0 & 0,946 \\
\hline Sesudah & $-1,70$ & \pm & 1,2 & $-1,90$ & \pm & 1,1 & $-2,19$ & \pm & 1,2 & 0,411 \\
\hline Selisih & 0,40 & \pm & 0,5 & 0,20 & \pm & 0,4 & 0,03 & \pm & 0,5 & $0,034^{*}$ \\
\hline $\mathrm{p}^{\mathrm{b}}$ & \multicolumn{3}{|c|}{$0,011^{*}$} & \multicolumn{3}{|c|}{$0,032^{*}$} & \multicolumn{3}{|c|}{0,812} & \\
\hline
\end{tabular}

Keterangan: $\mathrm{BB} / \mathrm{U}=$ berat badan per umur; ${ }^{*}=$ bermakna $(p<0,05) ;{ }^{a}$ perbedaan antar kelompok; ${ }^{\mathrm{b}}$ perbedaan di dalam kelompok

Tabel 5. Kandungan gizi tiga jenis biskuit per 100 gram

\begin{tabular}{lcccccccc}
\hline \multirow{2}{*}{ Jenis } & $\begin{array}{c}\text { Energi } \\
\text { (kal) }\end{array}$ & $\begin{array}{c}\text { KH } \\
(\mathbf{g})\end{array}$ & $\begin{array}{c}\text { Protein } \\
(\mathbf{g})\end{array}$ & $\begin{array}{c}\text { Lemak } \\
(\mathbf{g})\end{array}$ & $\begin{array}{c}\text { Zn } \\
(\mathbf{m g})\end{array}$ & $\begin{array}{c}\text { Vit. A } \\
(\mathbf{I U )}\end{array}$ & $\begin{array}{c}\text { Vit. B6 } \\
(\mathbf{m g})\end{array}$ & $\begin{array}{c}\text { Vit. C } \\
(\mathbf{m g})\end{array}$ \\
\hline Tempe kurma & 485 & 66,10 & 8,44 & 22,60 & 1,28 & $<0,50$ & $<0,02$ & 0,82 \\
Tempe & 516 & 58,70 & 8,40 & 27,50 & 1,46 & $<0,50$ & $<0,02$ & 0,77 \\
Plasebo & 462 & 70,40 & 5,03 & 17,80 & 1,28 & $<0,50$ & $<0,02$ & $<0,20$ \\
\hline
\end{tabular}

Sumber: Laboratorium Balai Besar Industri Agro (BBIA), Bogor 2012; 1 RE = 3,33 IU; kandungan vitamin A dalam tiap biskuit adalah $<0,5 \mathrm{IU}=<1,67 \mathrm{RE}$

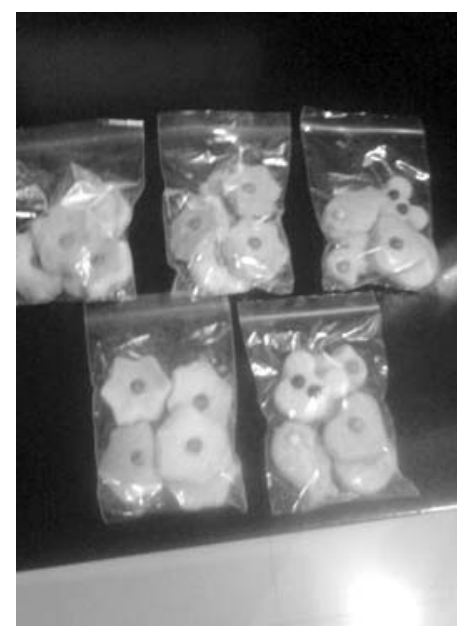

Gambar 1. Biskuit plasebo

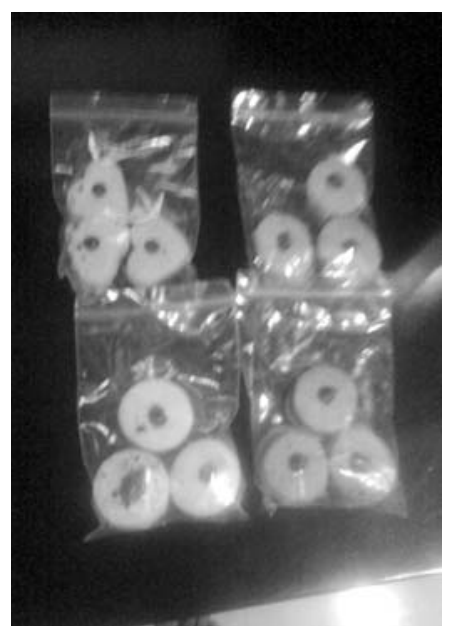

Gambar 2. Biskuit tempe

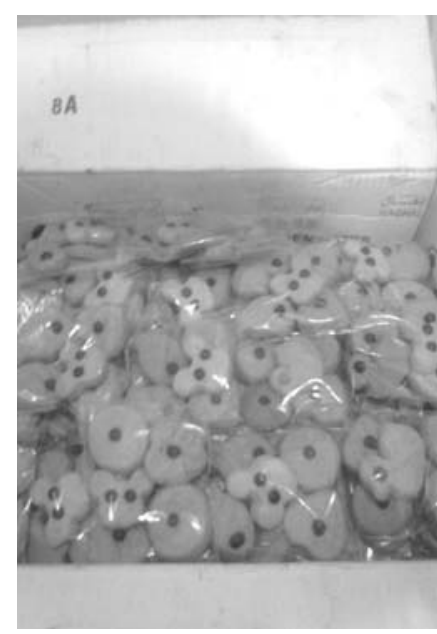

Gambar 3. Biskuit tempe kurma

\section{BAHASAN}

Melalui konsumsi 100 gram biskuit tempe kurma, maka pemenuhan angka kecukupan gizi (AKG) energi, karbohidrat, protein, dan vitamin $\mathrm{C}$ anak 1-3 tahun dapat tercukupi berturut-turut sekitar $48,5 \% ; 40 \% ; 33,8 \%$; dan $2,1 \%$. Sementara itu, pada anak 4-6 tahun akan tercukupi kebutuhan energinya sebesar $31,3 \% ; 30 \%$ karbohidrat;
$21,6 \%$ protein; dan $1,8 \%$ vitamin C (16). Dengan demikian, dalam penelitian ini kebutuhan energi anak usia 1-3 tahun dapat terpenuhi sebesar 24,25\% AKG; $20 \%$ AKG karbohidrat; $16,9 \%$ AKG protein; dan 1,05\% AKG vitamin $C$ bila mengonsumsi 50 gram biskuit tempe kurma per harinya. Sementara anak usia 4-5 tahun akan tercukupi kebutuhan 15,65\% AKG energi; 15\% AKG karbohidrat; $10,8 \%$ AKG protein; dan 0,9\% AKG vitamin C. 
Perubahan berat badan paling pesat dimiliki oleh subjek penerima biskuit tempe kurma. Peningkatan berat badan ini disebabkan oleh asupan karbohidrat yang paling besar pada kelompok biskuit tempe kurma dibandingkan dua kelompok kontrol. Tingginya asupan karbohidrat ini mungkin diperoleh dari kandungan glukosa dan fruktosa dalam kurma yang langsung dapat dicerna oleh tubuh menjadi energi (11). Pemenuhan kebutuhan karbohidratnya sebesar $20 \%$ diperoleh dari konsumsi biskuit tempe kurma pada anak 1-3 tahun dan 15\% karbohidrat pada anak 4-5 tahun.

Sementara itu, subjek pada kelompok biskuit tempe mengalami kenaikan tinggi badan paling besar dibandingkan dua kelompok lainnya. Hal ini dipengaruhi oleh pengetahuan ibu balita tentang gizi dan penyakit TB pada kelompok biskuit tempe yang juga ditemukan mengalami peningkatan paling tinggi. Pengetahuan ibu balita tentang gizi dan TB mempengaruhi tingkat konsumsi biskuit tempe yang berdampak pada kenaikan tinggi badan paling pesat pada kelompok ini. Temuan terakhir ini sejalan dengan studi serupa yang dilakukan di Jakarta Timur (8) dan studi di Kabupaten Sragen (17) dan Ghana (18). Pengetahuan ibu tentang gizi berhubungan secara bermakna dengan status gizi balita. Intervensi pendidikan gizi pada orang tua atau keluarga yang mempunyai anak balita akan merubah perilaku ibu dan keluarga dalam hal pemberian makan pada anak sehingga akan meningkatkan status gizi anak balitanya (19).

Hasil penelitian ini menunjukkan bahwa kenaikan berat badan tertinggi ditemukan pada kelompok biskuit tempe kurma yang sejalan dengan tiga studi sebelumnya. Studi pertama membuktikan adanya perbedaan bermakna berat badan dan tinggi badan melalui pemberian biskuit dari tepung kentang bagi balita gizi kurang di India selama 3 bulan. Studi kedua dilakukan pada balita gizi kurang di Kota Depok yang membuktikan kenaikan berat badan sebesar 1,3 kg pada kelompok biskuit tempe kurma selama 4 minggu. Studi ketiga membuktikan suplementasi multimikronutrien pada balita gizi kurang dapat meningkatkan berat badan balita selama 4 bulan intervensi. Perbedaan perubahan berat badan hasil penelitian ini dengan ketiga studi tersebut disebabkan oleh adanya penyakit infeksi penyerta dari TB yang diderita oleh subjek pada penelitian ini. Lama intervensi diduga juga berperan pada perbedaan kenaikan berat badan pasca intervensi $(3,7,20)$.

Asupan gizi yang memadai selama masa pengobatan seringkali belum meningkatkan berat badan anak selama 6 bulan pengobatan. Peningkatan berat badan yang ada biasanya berasal dari massa lemak sedangkan massa bebas lemak termasuk protein membutuhkan waktu lebih lama (21). Diduga peningkatan berat badan subjek penerima ketiga jenis biskuit berasal dari massa lemak dan bukan dari massa bebas lemak. Namun, hal ini perlu didukung lebih lanjut oleh pemeriksaan lemak. Asupan zat gizi mikro antar kelompok tidak menunjukkan adanya perbedaan bermakna kecuali vitamin $\mathrm{C}$, hal ini mungkin disebabkan oleh lama studi yang tergolong singkat yaitu selama 4 minggu. Bila dilakukan selama 3 bulan yang didukung dengan pemeriksaan biokimiawi seperti kadar albumin darah dan $\mathrm{Hb}$ mungkin bisa berbeda bermakna pada ketiga kelompok. Perbedaan asupan vitamin $\mathrm{C}$ antar kelompok mungkin disebabkan oleh tingginya kandungan vitamin $C$ dalam 100 gram biskuit tempe kurma. Studi membuktikan adanya hubungan antara defisensi vitamin C dengan penyakit TB. Suplementasi vitamin $C$ dapat mematikan pembiakan bakteri Mycobacterium tuberculosis. Demikian pula suplementasi vitamin $D$, vitamin $A$, dan $\mathrm{Fe}$ dapat memperbaiki imunitas tubuh pasien TB (10).

Studi ini memiliki beberapa keterbatasan yaitu minimnya jumlah sampel yang tetap bertahan hingga akhir studi. Semula terdapat 60 sampel yang berpartisipasi penuh mengikuti penelitian, tetapi pada minggu kedua sebanyak 11 sampel drop-out sehingga total sampel menjadi 49 subjek. Status penyakit TB subjek pada penelitian ini juga berbeda yaitu ada yang baru menjalani fase intensif dan ada yang sedang menjalani fase lanjutan atau bahkan hampir menyelesaikan pengobatan lanjutan sehingga menyebabkan kenaikan berat badan tidak sepesat pada balita TB yang baru memulai pengobatan fase intensifnya.

Berdasarkan hasil penelitian ini, dapat disimpulkan bahwa biskuit ini dapat dijadikan alternatif bentuk pangan program PMT pemulihan bagi balita TB yang baru memasuki tahap pengobatan awal agar diperoleh kenaikan berat badan paling maksimal dibandingkan dengan balita TB yang sedang menjalani pengobatan atau akan mengakhiri fase lanjutan OAT-nya.

\section{SIMPULAN DAN SARAN}

Kenaikan berat badan terbesar $(0,5 \mathrm{~kg})$ terdapat pada balita penerima biskuit tempe kurma sedangkan peningkatan tinggi badan terbesar $(1,8 \mathrm{~cm})$ pada balita kelompok biskuit tempe. Disarankan agar biskuit tempe kurma dijadikan alternatif makanan PMT pemulihan bagi balita gizi kurang penderita TB maupun non penderita TB di Kota Depok.

\section{UCAPAN TERIMA KASIH}

Ucapan terima kasih ditujukan pada DP2M Dikti Kemendikbud yang telah mendanai kegiatan ini melalui Hibah Pengabdian Masyarakat Tahun 2012.

\section{RUJUKAN}

1. WHO. WHO report 2009. [series online] 2009 [cited 2013 Jan 5]. Available from: URL: http.//www.who.int/ tb/publications/global_report/2009 
2. Gupta KB, Gupta R, Atreja A, Verma M, Vishvkarma S. Tuberculosis and nutrition. Lung India 2009;26(1):916.

3. Vasanta M, Gopi PG, Subramani R. Weight gain inpatients with tuberculosis under directly observed treatment short-course (DOTS). Indian J Tuberc 2009;56(1):5-9.

4. Yew WW, Leung CC. Antituberculosis drugs and hepatotoxicity. Respirology 2006;11(6):699-707.

5. Dinas Kesehatan Kota Depok. Laporan penilaian status gizi (PSG) Depok. Depok: Dinkes Depok; 2010.

6. Taslim AN. Nutrition campaign, soy protein supplementation and rehabilitation on tuberculosis patients in Makassar, South Sulawesi. J Med Nus 2006;25:59-64.

7. Fatmah, Diva F, Dian P, Ivonne MI, Triyani. Tempehdates biscuits effect on the gained weight of moderate underweight children. Int J Med Med Sci 2012;2(8):16572.

8. Fatmah. Laporan penelitian pengaruh biskuit tempe kurma pada status gizi balita TBC. Depok: FKM-UI; 2012.

9. Condé Nast-Self Nutrition Data. Nutrition facts of tempeh. [series online] 2013 [cited 2013 Feb 2]. Available from: URL: http.//www.nutritiondata.self.com facts/legumes-and-legume-products/4381/2

10. NICUS (Nutrition Information Center). Tuberculosis (TB) and nutrition. Tygerberg: University of Stellenbosch; 2007.

11. Badwilan AS. The miracle of dates: the natural healthy secret with date. Bandung: Mizan; 2008.
12. WHO. World health organization multicentre growth reference study group. WHO child growth standards: length/height-for-age, weight-for-age, weight-for-length, weight-for-height and body mass index-for-age: methods and development. Geneva, Switzerland: WHO; 2006.

13. Rizal E, Hidayanti L. Dampak pemberian makanan tambahan (PMT) lokal terhadap peningkatan status gizi (BB/TB skor z) pada balita gizi kurus [Skripsi]. Tasikmalaya: Universitas Siliwangi; 2012.

14. Kemendikbud. Sistim Pendidikan Nasional (SISDIKNAS) 2012. Jakarta: Nuansa Aulia; 2012.

15. WHO. WHO anthroplus software license manual. Geneva, Switzerland: WHO; 2009.

16. Departemen Kesehatan RI. Widyakarya nasional pangan dan gizi (WNPG) tahun 2004. Jakarta: Depkes $\mathrm{RI} ; 2004$.

17. Munthofiah S. Hubungan antara pengetahuan, sikap, dan perilaku ibu dengan status gizi anak balita [Tesis]. Surakarta: Universitas Negeri Sebelas Maret; 2008.

18. Appoh LY, Krekling S. Maternal nutritional knowledge and child nutritional status in the Volta region of Ghana. Matern Child Nutr 2005;1(2):100-10.

19. Frost MB, Forste R, Haas DW. Maternal education and child nutritional status in Bolivia. Soc Sci Med 2005;60(2):395-407.

20. Mursalim, Juffrie M, Nenny Sri M. Pemberian fortifikasi multi-mikronutrien berpengaruh terhadap pertumbuhan balita keluarga miskin. Jurnal Gizi Klinik Indonesia 2011;8(2):65-76.

21. Beisel WR, Fiser RH. Lipid metabolism during infectious illness. Am J Clin Nutr 1970;23(8):1069-107. 